\title{
APPLYING RISK PROFILE, GOOD CORPORATE GOVERNANCE, EARNING AND CAPITAL (RGEC) METHOD TO PREDICT THE BANK HEALTH (CASE STUDY ON PT. BANK TABUNGAN NEGARA)
}

\author{
Zainuddin $^{1}$, Yustiana Djaelani ${ }^{2}$ \\ ${ }^{1,2}$ Accounting Program, Economics and Business Faculty, Khairun University, Jl. Jusuf Abdulrahman, Ternate, \\ 97719, Indonesia
}

Corresponding e-mail : zainudin@unkhair.ac.id

\begin{abstract}
This study aimed to analyze the health of PT. Bank Tabungan Negara (Persero) Tbk over period of 2013 to 2017 RGEC method approach (Risk Profile, Good Corporate Governance, Earnings, Capital). This research is quantitative descriptive method. The variables in this study include Risk Profile using the ratio of Non Performing Loans (NPLs) and loan to Deposits Ratio (LDR), GCG using Composite Rating GCG, Earnings use ratios Return on Assets (ROA) and Net Interest Margin (NIM) and Last Capital uses Adequacy Capital ratio $(C A R)$. The results showed Bank BTN predicate healthy enough where banks are still quite capable of carrying out risk-based banking management well, so they deserve to be trusted community. However, the calculation of the proportion of Loan to Deposits Ratio (LDR) is below standard bank of Indonesia with the predicate less healthy.
\end{abstract}

Keywords: risk profile, good corporate governance, earnings, capital

JEL Classification : H10, H11

Article info:

Received 30 November 2018

Revised 17 December 2018

Accepted 22 December 2018

Available online 31 December 2018

\section{INTRODUCTION}

The monetary crisis of Indonesia in mid-1997 could be used as a lesson for banking sector where the crisis began with liquidity difficulties due to the decline in the IDR exchange rate against the USD. The crisis caused the revocation of the business of 16 private banks and the takeover of bank management because the amount of BLBI had exceeded $200 \%$ by the Minister of Finance. The banking crisis again occurred in Indonesia in year of 2008 where the crisis had a systemic impact on the banking sector, so the interest rate was lowered to increase consumption and investment. The recurrence of the banking crisis occurred because banks are trust institutions that are vulnerable to massive withdrawals by customers. The crisis disrupted bank financial intermediation activities which then led to increasingly fierce competition, especially in terms of attracting public interest in saving funds in banks. In its development, competition between banks is seen from their efforts to obtain customer funds because these funds are very important for banks as a source of funds used for bank operations. Banks are now more flexible in the services provided not only as a place for storing money for surplus parties (surplus fund) and as a source of funds for those who need funds (deficit fund).

The health of a bank is very important to establish the public trust in the world of banking. Kuncoro and Suhardjo (2011: 495) state that trust and customer loyalty to banks is a factor that is very helpful and facilitates the bank's management to develop a good business strategy. Conversely, customers who lack trust in the bank concerned are also very thin in 
loyalty, this is certainly very unfavorable for the bank concerned because the fund owners or customers can withdraw funds at any time and transfer them to another bank. Therefore, banks are required to be able to achieve and maintain a good and optimal level of performance because a good level of bank performance can increase the trust and loyalty of customers and the wider community to use products, services and financial activities of the bank. Bank Indonesia has set rules regarding bank health so that banks are expected to always be in good health, so that they will not harm the public with an interest in banking. Bank health can be interpreted as the ability of a bank to carry out banking operations normally and be able to fulfill all its obligations properly in ways that comply with applicable banking regulations (Triandaru and Budisantoso, 2006: 51).

The bank soundness rating is used to determine whether the bank is in a very healthy, healthy, fairly healthy, unhealthy or unhealthy condition. A healthy bank is a bank that can maintain and maintain public trust, can carry out the intermediary function, can help smooth payment traffic and can be used by the government in implementing various policies, especially monetary policy. Unhealthy banks are not only endanger the banking sector but also other parties involved namely the owner and manager of the bank, the community using the services of the bank and the Government (Central Bank of Indonesia) as the supervisor and supervisor of the bank.

Previously, the rating system for commercial banks use valuation system which set in Regulation of Central Bank of Indonesia Number 6/10/PBI/2004 known as the CAMELS method, consisting of Capital, Asset quality, Management, Earnings, Liquidity \& Sensitivity to market risk. Whereas the method or approach used in assessing the health of banks currently refers to Bank Indonesia Regulation No.13/1/PBI/2011 concerning Assessment of Soundness Levels of Commercial Banks, namely by using a Risk-based Bank Rating both individually and consolidation, with the scope of the assessment covering the following factors: Risk Profile (risk profile), Good Corporate Governance (GCG), Profitability (earnings); and Capital (capital) or abbreviated as the RGEC method. Changes in the rating system for commercial banks from the CAMELS method became the RGEC method due to the global financial crisis that occurred in the last few years giving valuable lessons that innovation in banking products, services and activities that are not balanced with the application of adequate Risk Management can lead to various fundamental problems with banks as well as the financial system as a whole. In addition, the failure of strategies and fraudulent practices of top management also took place without being detected and caused the importance of implementing good corporate governance (GCG).

The experience of the global financial crisis has encouraged the need to increase the effectiveness of the application of Risk Management and GCG. The aim is banks to be able to identify problems earlier, carry out appropriate and faster corrective actions, and implement better GCG and Risk Management so that banks are more resilient in facing crises. In line with the aforementioned developments, Central Bank of Indonesia refined the method for assessing the soundness of commercial banks. This study takes PT. Bank Tabungan Negara (BTN) as the the object because bank as one of the state-owned banks that continued to grow and develop. Looking at the very large role of BTN in the Indonesian economy and as one of the companies managed directly by the government, it is expected that the BTN can improve or maintain its performance to the maximum so that it will positively affect the national economy as a whole. As a bank that serves many people, it is required to continue to maintain its health. Liquidation or bankruptcy of a large bank can lead to bankruptcy of another bank due to sudden withdrawal of funds (Latumaerissa, 2012: 144). Looking at the very strategic role of the BTN, the health and stability of the BTN is very vital. Therefore the researcher felt it was important to conduct an analysis at the BTN to find out the health condition of the bank. 


\section{LITERATURE REVIEWS}

Evaluation concept. Wirawan (2011: 30) states that evaluation is a tool of various branches of science to analyze and assess the phenomenon of science and the application of science in the application of science. This study uses inequality evaluation model wherein in evaluating the analysis of the assessment of the soundness of state-owned commercial banks in period of 2012 to 2014 by using existing standards namely Central Bank of Indonesia Regulation No.13/1/PBI/2011 and Circular of Central Bank of Indonesia No.13/24/DPNP. Inequality evaluation model was developed by Malcolm M. Provus in 1971. According to Provus in Wirawan (2011: 106) states that evaluation is an art (painting) illustrates the inequality between performance standards and performance that occurs.

Bank. The Law No. 7 year of 1992 concerning Banking as amended by Law No. 10 of 1998 explains that a Bank is a business entity that collects funds from the public in the form of deposits and distributes them to the public in the form of loans and/or other forms in order to improve the standard of living of many people. Based on BI Regulation No.9/7/PBI/2007, Commercial Banks can be defined as banks that carry out conventional business activities and/or based on sharia principles whose activities provide services in payment traffic. According to Hasibuan (2009: 2) Commercial banks are financial institutions, money creators, fund collectors and credit channelers, implementers of payment traffic, monetary stabilizers, and dynamic economic growth.

Bank health. Bank health can be interpreted as the ability of a bank to carry out banking operations normally and be able to fulfill all its obligations properly in ways that comply with applicable banking regulations (Triandaru and Budisantoso, 2006: 51). According to Rivai et al. (2012: 465) Health or financial and non-financial conditions of banks are in the interests of all parties involved, owners, bank management, government banks (through Bank Indonesia) and bank service users. By knowing the condition of a bank it can be used by these parties to evaluate the performance of the bank in applying the principle of prudence, compliance with applicable regulations and risk management. The development of the banking industry, especially products and services that are increasingly complex and diverse will increase the risk exposure faced by banks. Changes in bank risk exposure and the application of risk management will affect the bank's risk profile which in turn results in the overall condition of the bank. The development of the bank's condition assessment methodology is dynamic so that the bank's health assessment system is constantly adjusted to better reflect the true condition of the bank, both now and in the future. The rearrangement of these includes the improvement of the assessment approach (quantitative and qualitative) and the addition of assessment factors when necessary. For banks, the results of the assessment of the condition of the bank can be used as a means of establishing a business strategy in the future, while for Bank Indonesia it can be used as a means of policy determination and implementation of supervision strategies, so that at the appointed time the bank can implement a level rating system proper bank health.

Valuation method of banking health. Based on regulation of Central Bank of Indonesia No.13/1/PBI/2011 concerning Assessment of Health Levels of Commercial Banks, the Central Bank of Indonesia has established a system for assessing the health of banks using the Risk-based Bank Rating/RBBR approach both individually and on a consolidated basis, with the scope of the assessment includes the following factors: Risk Profile, Good Corporate Governance (GCG), Profit (earnings) and Capital (capital) or abbreviated as the RGEC method replacing the CAMELS assessment which was previously regulated in PBI No.6/10/PBI/2004. In the Circular of Central Bank of Indonesia No.13/24/DPNP dated October $25^{\text {th }}$ of 2011 concerning the Evaluation of the Health Level of Commercial Banks, the assessment of RGEC factors consists of: 
1. Risk profile. The assessment of risk profile factors is assessed on the inherent risks and the quality of the application of risk management in bank operations to eight risks, namely credit risk, market risk, liquidity risk, operational risk, legal risk, strategic risk, compliance risk and reputation risk. In this study the researchers measured the risk profile factor by using 2 indicators, namely credit risk factors using the NPL formula and liquidity risk with the LDR formula.

Loan risk. Credit risk is a risk due to the failure of the debtor and/or other parties to fulfill obligations to the Bank. Credit risk is generally found in all Bank activities whose performance depends on the performance of the counterparty, issuer, or the performance of the borrowing borrower (borrower). Credit risk can also be caused by concentrating the provision of funds to debtors, geographical areas, products, types of financing, or certain business fields. Credit risk by calculating the Non Performing Loan ratio based on Circular Letter of Central Bank of Indonesia No. 13/24/DPNP/2011:

$$
\mathrm{NPL}=\frac{\text { Impaired loans }}{\text { Total loans }} \times 100 \%
$$

Table 1. Rating criteria matrix of Non Performing Loan (NPL)

\begin{tabular}{ccc}
\hline Rating & Description & Criteria \\
\hline 1 & Very health & $0 \%<\mathrm{NPL}<2 \%$ \\
2 & Health & $2 \% \leq \mathrm{NPL}<5 \%$ \\
3 & Health enough & $5 \% \leq \mathrm{NPL}<8 \%$ \\
4 & Less health & $8 \%<\mathrm{NPL} \leq 11 \%$ \\
5 & Unhealth & $\mathrm{NPL}>11 \%$ \\
\hline
\end{tabular}

Source: Codification Bank Health Rating, 2012

Liquidity risk. Liquidity risk is the risk due to the inability of the bank to meet the maturing obligations of the cash flow funding sources, and/or from high-quality liquid assets that can be pledged, without disrupting the bank's activities and financial conditions. This risk is also called funding liquidity risk. Liquidity risk can also be caused by the inability of banks to liquidate assets without being subject to material discounts due to the absence of active markets or severe market disruption. This risk is referred to as market liquidity risk. Liquidity risk by calculating the Loan to Deposit Ratio ratio based on Circular Letter of Central Bank of Indonesia No. 13/24/DPNP/2011 :

$$
\text { LDR }=\frac{\text { Total loans }}{\text { Fund of third parties }} \times 100 \%
$$

Table 2. Rating criteria matrix of Loan to Deposit Ratio (LDR)

\begin{tabular}{ccc}
\hline Rating & Description & Criteria \\
\hline 1 & Very health & $50 \%<\mathrm{LDR} \leq 75 \%$ \\
2 & Health & $75 \%<\mathrm{LDR} \leq 85 \%$ \\
3 & Health enough & $85 \%<\mathrm{LDR} \leq 100 \%$ \\
4 & Less health & $100 \%<\mathrm{LDR} \leq 120 \%$ \\
5 & Unhealth & $\mathrm{LDR}>120 \%$ \\
\hline
\end{tabular}

Source: Codification Bank Health Rating, 2012

2. Valuation of Good Corporate Governance (GCG). GCG factor assessment is an evaluation of the quality of the Bank's management in implementing GCG principles. The principles of GCG and the focus of assessment on the implementation of GCG principles 
are guided by Bank Indonesia regulations regarding GCG Implementation for Commercial Banks by taking into account the characteristics and complexity of the Bank's business. Assessing the implementation of bank GCG considers the factors of GCG assessment in a comprehensive and structured manner, including governance structur, governance process, and governance outcome. Based on Circular Letter of Central Bank of Indonesia No. 15/15/DPNP of year 2013 banks were required to conduct self assessments on the implementation of GCG. The GCG composite value helps researchers to see the GCG conditions of each bank based on Circular Letter of Central Bank of Indonesia No. 9/12/DPNP/2007.

Table 3. Rating criteria matrix of Good Corporate Governance

\begin{tabular}{ccc}
\hline Rating & Description & Criteria \\
\hline 1 & Very health & $\mathrm{NK}<1,5$ \\
2 & Health & $\mathrm{NK} 1,5 \leq \mathrm{NK}<2,5$ \\
3 & Health enough & $\mathrm{NK} 2,5 \leq \mathrm{NK}<3,5$ \\
4 & Less health & $\mathrm{NK} 3,5 \leq \mathrm{NK}<4,5$ \\
5 & Unhealth & $\mathrm{NK} 4,5 \leq \mathrm{NK}<5$ \\
\hline
\end{tabular}

Notes: NK is composit value.

3. Profitability/earnings valuation. Assessment of profitability factors includes evaluating earnings performance, sources of profitability, sustainability of profitability, and management of profitability. Assessment is carried out by considering the level, trend, structure, stability of bank profitability, and comparison of bank performance with peer group performance both through analysis of quantitative and qualitative aspects. Based on Circular Letter of Central Bank of Indonesia No.13/24/DPNP/2011 the assessment of earnings factors is based on two ratios, namely:

Return on assets (ROA)

$$
\text { ROA }=\frac{\text { Earnings before tax }}{\text { Average of total assets }} \times 100 \%
$$

Table 4. Rating criteria matrix of Return on Assets (ROA)

\begin{tabular}{ccc}
\hline Rating & Description & Criteria \\
\hline 1 & Very health & $\mathrm{ROA}>1,5 \%$ \\
2 & Health & $1,25 \%<\mathrm{ROA} \leq 1,5 \%$ \\
3 & Health enough & $0,5 \%<\mathrm{ROA} \leq 1,25 \%$ \\
4 & Less health & $0 \%<\mathrm{ROA} \leq 0,5 \%$ \\
5 & Unhealth & $\mathrm{ROA} \leq 0 \%$ \\
\hline
\end{tabular}

Net Interest Margin (NIM)

$$
\mathrm{NIM}=\frac{\text { Average of interest income }}{\text { Average of assets productive }} \times 100 \%
$$


Table 5. Rating criteria matrix of Net Interest Margin (NIM)

\begin{tabular}{ccc}
\hline Rating & Description & Criteria \\
\hline 1 & Very health & $3 \%>\mathrm{NIM}$ \\
2 & Health & $2 \%<\mathrm{NIM} \leq 3 \%$ \\
3 & Health enough & $1,5 \%<\mathrm{NIM} \leq 2 \%$ \\
4 & Less health & $1 \%<\mathrm{NIM} \leq 1,5 \%$ \\
5 & Unhealth & $\mathrm{NIM} \leq 1 \%$ \\
\hline
\end{tabular}

Source: Codification Bank Health Rating, 2012

4. Capital valuation. Assessments of capital factors include evaluating the adequacy of capital and the adequacy of capital management. In calculating capital, banks must refer to Bank Indonesia regulations governing the obligation to provide minimum capital for commercial banks. In addition, in assessing capital adequacy, banks must also link capital adequacy with the bank's risk profile. The higher the bank's risk, the more capital must be provided to anticipate the risk. Based on Circular Letter of Central Bank of Indonesia No. 13/24/DPNP/2011 the capital adequacy ratio by calculating the Capital Adequacy Ratio:

$$
\mathrm{CAR}=\frac{\text { Bank capital }}{\text { Risk-based average assets }} \times 100 \%
$$

Table 6. Rating criteria matrix of Capital Adequacy Ratio (CAR)

\begin{tabular}{ccc}
\hline Rating & Description & Criteria \\
\hline 1 & Very health & CAR $\geq 11 \%$ \\
2 & Health & $9,5 \% \leq \mathrm{CAR}<11 \%$ \\
3 & Health enough & $8 \% \leq \mathrm{CAR}<9,5 \%$ \\
4 & Less health & $6,5 \% \leq \mathrm{CAR}<8 \%$ \\
5 & Unhealth & $\mathrm{CAR}<6,5 \%$ \\
\hline
\end{tabular}

Source: Codification Bank Health Rating, 2012

5. Assessment of composite rating of bank health. Composite rating of bank health level is determined based on a comprehensive and structured analysis of the ratings of each factor and by taking into account the general principles of rating the health of commercial banks. 
Table 7. Rating criteria matrix of composite rating

Rating Description

PK 1 Reflecting the condition of banks that are generally very healthy so that they are considered to be able to deal with significant negative effects of changes in business conditions and other external factors reflected in the ratings of assessment factors, including risk profiles, implementation of GCG, profitability and capital which are generally very good . If there are weaknesses, in general these weaknesses are not significant.

PK 2 Reflecting the condition of banks that are generally health so that they are considered capable of facing significant negative effects from changes in business conditions and other external factors reflected in the ratings of assessment factors, including risk profiles, implementation of GCG, profitability, and generally good capital. If there are weaknesses, in general these weaknesses are less significant.

PK 3 Reflecting the condition of banks that are generally health enough to be considered capable of dealing with significant negative effects of changes in business conditions and other external factors reflected in the ratings of assessment factors, including risk profiles, implementation of GCG, profitability, and capital which are generally quite good . If there are weaknesses, in general these weaknesses are quite significant and if it is not managed properly, management can disrupt the continuity of the bank's business.

PK 4 Reflecting the condition of banks that are generally less health so that they are considered to be unable to deal with significant negative effects of changes in business conditions and other external factors reflected in ratings of assessment factors, including risk profiles, implementation of GCG, profitability, and capital which are generally poor . There are generally significant weaknesses.

PK 5 Reflecting the condition of banks that are generally unhealthy so that they are considered unable to deal with significant negative effects of changes in business conditions and other external factors reflected in the ratings of assessment factors, including risk profiles, implementation of GCG, profitability, and capital which are generally not good enough . There are weaknesses that are generally very significant so that to overcome them, financial support from shareholders or sources of funds from other parties is needed to strengthen the bank's financial condition.

Source: Circular Letter of Central Bank of Indonesia No. 13/24/DPNP/2011

On the analysis of each component with the calculation of financial ratios to be implemented, the results to be obtained in this study will be obtained to analyze the health of the bank at a certain Composite Rating. So that it can make a decision in assessing financial performance for the continuity of business banking and providing information to internal and external parties that will increase the level of trust in the bank and vice versa. The composite value for financial ratios of each component that is ranked composite will be of the following values:

a. Rank $1=$ every time the checklist is multiplied by 5

b. Rank $2=$ every time the checklist is multiplied by 4

c. Rank $3=$ every time the checklist is multiplied by 3

d. Rank $4=$ every time the checklist is multiplied by 2

e. Rank 5 = every time the checklist is multiplied by 1

The composite value that has been obtained from multiplying each checklist is then determined by weighting. As for the weights/percentages to rank composite components as follows: 
Table 8. Composite Rating of Bank Health by RGEC Method

\begin{tabular}{ccc}
\hline Point & Composite Rating & Description \\
\hline $86-100$ & PK 1 & Very health \\
$71-85$ & PK 2 & Health \\
$61-70$ & PK 3 & Health enough \\
$41-60$ & PK 4 & Less health \\
$<40$ & PK 5 & Unhealth \\
\hline
\end{tabular}

Source: Refmasari and Ngadirin Setiawan in 2014

Study framework. Financial statement analysis converts data from financial statements into information. Analysis of financial statements consists of various techniques which is used. This study will analyze financial statements to assess the health of state-owned commercial banks based on Regulation of Central Bank of Indonesia No.13/1/PBI/2011 concerning Health Rating for Commercial Banks. The bank health rating system using the risk approach (Risk-based Bank Rating/RBBR) with the scope of the assessment includes the following factors: Risk Profile, Good Corporate Governance (GCG), Profitability; and Capital (capital) or abbreviated as the RGEC method. The Risk Profile factor of this study is credit risk by calculating the NPL (Non Performing Loan) and liquidity risk by calculating the LDR (Loan to Deposit Ratio). The Good Corporate Governance (GCG) factor is taken from the annual report of each bank that conducts a self assessment of the implementation of GCG. While for the Earning assessment factor used is the ratio of ROA (Return on Assets), NIM (Net Interest Margin). The capital factor of this study is CAR (Capital Adequacy Ratio). The results of the calculation of the ratio of some of these indicators are then determined by the composite rating so that it will be known whether the PT. Bank Tabungan Negara (Persero) is very healthy, healthy, fairly healthy, less healthy, or unhealthy.

\section{RESEARCH METHOD}

The object of this study is PT. Bank Tabungan Negara (Persero) Tbk. over period of 2013 to 2017 by assessing the health of bank with the scope of the assessment covering the following factors: Risk profile, Good Corporate Governance (GCG), Profitability (Earnings) and Capital (Capital). The type of data used in this study is secondary data drawn from the publication of financial statements of PT. Bank Tabungan Negara (Persero) Tbk. which consists of statements of financial position, income statement, and bank annual report notes for the period 2013 to 2017.

The data analysis method of this study is the technique of analyzing the health of the bank using the Risk approach (Risk-based Bank Rating/RBBR) with the scope of the assessment covering the following factors: Risk profile, Good Corporate Governance (GCG), Profitability (Earnings) and Capital (Capital) or abbreviated as the RGEC method. For the risk profile factor in this study used is credit risk by calculating the NPL (Non Performing Loan) and liquidity risk by calculating the LDR (Loan to Deposit Ratio). The Good Corporate Governance (GCG) factor is taken from the annual report of each bank that conducts a self assessment of the implementation of GCG. As for the factor of rentability, the valuation used is the ratio of ROA (Return on Assets), NIM (Net Interest Margin). The capital factor in this study used is CAR (Capital Adequacy Ratio).

Composite rating of bank health level is determined based on a comprehensive and structured analysis of the ratings of each factor and by taking into account the general principles of rating the soundness of commercial banks. Determination of composite ranking are categorized into 5 (five) categories which are Composite Rating 1 (PK-1), Composite Rating 2 (PK-2), Composite Rating 3 (PK-3), Composite Rating 4 (PK-4), and Composite Rating 5 (PK-5). The order of smaller Composite Ranks reflects a healthier bank condition. 


\section{RESULTS AND DISCUSSIONS}

\subsection{Results}

The valuation of bank health based on regulation of Central Bank of Indonesia No. 13/1/PBI/2011 and Circular Letter of Central Bank of Indonesia No. 13/24/ DPNP on PT. Bank Tabungan Negara (BTN) which listed on Indonesia Stock Exchange over 2013 to 2017 are as follows:

1. Risk Profile. The financial ratios used to assess the health of BTN are NPL and LDR.

Non Performing Loan (NPL). The NPL ratio can show the ability of banks to manage non-performing loans from all loans provided by banks. The NPL ratio is obtained from non-performing loans, namely loans to third parties not classified as substandard, doubtful and loss divided by total loans to third parties not banks. Table 9 presents the results of the calculation of the BTN Bank NPL ratio for 2013-2017.

Table 9. Health of BTN based on NPL ratio

\begin{tabular}{ccc}
\hline Year & NPL & Criteria \\
\hline 2013 & $4,05 \%$ & Health \\
2014 & $4,01 \%$ & Health \\
2015 & $3,42 \%$ & Health \\
2016 & $2,84 \%$ & Health \\
2017 & $2,66 \%$ & Health \\
\hline
\end{tabular}

Source: processed data, 2019

Table 9 shows that the five-year NPL ratio of Bank BTN is positive, which is $4.05 \%$ in 2013 , down to $4.01 \%$ in 2014 , then decreases again to $3.42 \%$ in 2015 , fell to $2.84 \%$ in 2016 and dropped to $2.66 \%$ in 2017 so that the NPL value of BTN during 2013 to 2017 is categorized as health. However, based on the NPL value, BTN cannot yet be categorized as a bank with a very healthy category because the NPL ratio is still in the range of $2-5 \%$. Loan to Deposit Ratio (LDR). The LDR ratio is a comparison between total credit and non-bank third party funds consisting of savings, current accounts and time deposits. The LDR ratio is used to measure the comparison of the amount of credit provided by banks with funds received by banks, which illustrates the ability of banks to repay funds withdrawals by the public by relying on loans provided as a source of liquidity. Table 10 presents the results of the calculation of the 2013 to 2017 LDR from BTN.

Table 10. Health of BTN based on LDR ratio

\begin{tabular}{ccc}
\hline Year & LDR & Criteria \\
\hline 2013 & $104,42 \%$ & Less health \\
2014 & $108,86 \%$ & Less health \\
2015 & $108,78 \%$ & Less health \\
2016 & $102,66 \%$ & Less health \\
2017 & $103,13 \%$ & Less health \\
\hline
\end{tabular}

Source: processed data, 2019

Table 10 shows that the BTN LDR ratio for five years fluctuated but remained above $100 \%$, which was $104.42 \%$ in $2013,108.86 \%$ in $2014,108.78 \%$ in $2015,102.66 \%$ years 2016 and $103.13 \%$ in 2017 so that based on the LDR ratio above shows that BTN conditions during 2013-2017 are included in the criteria for Unhealthy. This shows that BTN liquidity is in a bad condition. The high LDR value at BTN is because the LDR calculation does not include long-term funding sources such as bonds, loans and 
repurchase agreements. As a bank that focuses on housing loans, most of the Company's assets are long-term loans, so long-term funding sources are needed.

2. Good Corporate Governance (GCG). GCG factor assessment is an evaluation of the quality of bank management on the implementation of GCG principles. The principles of GCG and the focus of assessment on the implementation of GCG principles are guided by Bank Indonesia regulations regarding GCG Implementation for Commercial Banks by taking into account the characteristics and complexity of the Bank's business. Assessing the implementation of bank GCG considers the factors of GCG assessment in a comprehensive and structured manner, including governance structure, governance process, and governance outcome. Based on the Circular Letter of Central Bank of Indonesia No. 15/15 / DPNP In 2013 banks were required to conduct self assessments on the implementation of GCG. The provision of GCG criteria is carried out by banks in self-assessment but remains under the supervision of Central Bank of Indonesia. Table 11 shows the results of the self-assessment carried out by BTN over period of 2013 to 2017:

Table 11. Health of BTN based on GCG

\begin{tabular}{ccc}
\hline Year & GCG & Criteria \\
\hline 2013 & 3 & Health enough \\
2014 & 2 & Health \\
2015 & 2 & Health \\
2016 & 2 & Health \\
2017 & 2 & Health \\
\hline
\end{tabular}

Source: processed data, 2019

Table 11 shows that the BTN GCG value for five years is GCG 3 in 2013 with a fairly healthy rating, and the same GCG value that is 2 in 2014 to 2017 with a Healthy rating. The lower GCG value indicates that the implementation of GCG is getting better. BTN's GCG value in 2013 was 3 with the criteria of being quite healthy due to the unfavorable implementation of GCG that year. In an effort to improve the implementation of GCG, BTN has taken steps in the form of an action plan to improve and improve the quality of GCG implementation that has been submitted to Bank Indonesia. In 2014 until 2017 the action plan gave a positive result which was proven by BTN GCG values which decreased to 2 with healthy criteria.

3. Profitability/Earnings. Financial ratios used in assessing the health of state-owned commercial banks in perspective of earnings are using two ratios which are Return on Assets (ROA) and Net Interest Margin (NIM).

Return on Assets (ROA). Return on Assets is a profitability ratio that is able to show the success of a bank in generating profits or profits by optimizing assets. This ratio is used to measure management success in generating profits. The smaller the ratio means the management of the bank is less able to manage assets to increase revenue and reduce costs. Table 12 presents the results of ROA ratio of BTN ratio from 2013 to 2017.

Table 12. Health of BTN based on ROA ratio

\begin{tabular}{ccc}
\hline Year & ROA & Criteria \\
\hline 2013 & $1,79 \%$ & Very health \\
2014 & $1,14 \%$ & Health enough \\
2015 & $1,61 \%$ & Very health \\
2016 & $1,76 \%$ & Very health \\
2017 & $1,71 \%$ & Very health \\
\hline
\end{tabular}

Source: processed data, 2019 
Based on the Table 12, it is known that the BTN's ROA ratio for five years are fluctuated where the ROA ratio in 2013, 2015, 2016 and 2017 was above the 1.5\%, which means that it was included in the category of Very Healthy banks but in 2014 ROA ratio of $1.14 \%$ or below the $1.5 \%$ rate so that it is categorized as ranked Healthy enough. BTN's ROA ratio in 2014 declined compared to 2013 due to a decrease in BTN profit in 2014, this decline in profit was due to an increase in interest rates which led to an increase in the Allowance for Impairment Losses (CKPN) at BTN. It was noted that in 2014 BTN's Reserve Allowance for Impairment Losses (CKPN) increased considerably from the previous year, namely from Rp430.29 billion in 2013 to Rp.771.17 billion in 2014, as part of the company's policy to increase the coverage ratio of problematic loans and if nonperforming loans can be resolved, the reserves will become one of the sources of income that will be received in the future.

Net Interest Margin (NIM). Net Interest Margin (NIM) is used as a measurement tool to determine the level of bank profitability obtained from net interest income on earning assets or assets that generate net interest. The NIM ratio is derived from net interest income divided by the average productive assets. Net interest income is interest income after deducting interest expense. Productive assets that are taken into account are assets that generate interest. The average earning assets in one period is obtained by adding up the value of the period's earliest earning assets with the value of the productive assets at the end of the period and then divided by two. Table 13 presents the results of the BTN's NIM ratio over period of 2013 to 2017.

Table 13. Health of BTN based on NIM ratio

\begin{tabular}{ccc}
\hline Year & NIM & Criteria \\
\hline 2013 & $5,44 \%$ & Very health \\
2014 & $4,47 \%$ & Very health \\
2015 & $4,87 \%$ & Very health \\
2016 & $4,98 \%$ & Very health \\
2017 & $4,76 \%$ & Very health \\
\hline
\end{tabular}

Source: processed data, 2019

Based on Table 13, it is known that the five-year BTN's NIM ratio is above 3\% as a standard category of banks with a Very Healthy rating. This can be seen from the 5-year NIM values of $5.44 \%$ in $2013,4.47 \%$ in $2014,4.87 \%$ in $2015,4.98 \%$ in 2016 and $4.76 \%$ in in 2017. The greater the value of the NIM indicates that banks are increasingly able to manage their productive assets to generate interest income so that bank profits will increase. During 2014 until 2016, BTN NIMs always increased, but in 2014, the BTN's NIM ratio decreased considerably, from $5.44 \%$ in 2013 to $4.47 \%$ in 2014 , a decline in the value of BTN's NIM occurred due to an increase in interest rates in 2014 which caused high interest costs so that BTN's net interest income declined. However, the overall ratio of net interest income (NIM) from BTN during 2013 to 2017 was in a very healthy condition.

4. Capital. The financial ratio used in assessing the soundness of the BTN bank in terms of capital aspects is the Capital Adequacy Ratio (CAR). CAR ratio is used to measure the capital adequacy of a bank to support assets that contain or produce risks. CAR is a ratio of comparison between Capital and Risk Weighted Assets. The risks referred to here are 3 risks, namely credit risk, operational risk and market risk. Capital calculation and Risk Weighted Assets (RWA) are guided by Bank Indonesia regulations concerning Minimum Capital Requirements for Commercial Banks (KPMM). Table 14 presents the results of the BTN's CAR ratio over period of 2013 to 2017. 
Table 14. Health of BTN based on CAR ratio

$\begin{array}{lcc}\text { Year } & \text { NIM } & \text { Criteria } \\ 2013 & 15,62 \% & \text { Very health } \\ 2014 & 14,63 \% & \text { Very health } \\ 2015 & 16,97 \% & \text { Very health } \\ 2016 & 20,34 \% & \text { Very health } \\ 2017 & 18,87 \% & \text { Very health }\end{array}$

Source: processed data, 2019

Table 14 shows that BTN's CAR ratio for five years is above $11 \%$ as a standard category of banks with a Very Healthy rating. This was seen by the value of consecutive CARs for 4 years at $15.62 \%$ in 2013 , decreasing to $14.63 \%$ in 2014 , increasing to $16.97 \%$ in 2015 , $20.34 \%$ in 2016 and $18,87 \%$ in 2017. Even though there was a decline in 2014 but it still above $11 \%$ so that BTN's CAR in period of 2013 to 2017 categorized as Very Healthy.

5. RGEC aspects (Risk profile, Good Corporate Governance, Earnings, and Capital). Table 15 presents the results of the BTN health rating based on the RGEC Method (Risk profile, Good Corporate Governance, earnings, and Capital) during 2013 to 2017.

Table 15. Determination of BTN's composite ranking based on the RGEC method in period of 2013 to 2017

\begin{tabular}{|c|c|c|c|c|c|c|c|c|c|c|}
\hline \multirow[b]{2}{*}{ Year } & \multirow[b]{2}{*}{ Factor } & \multirow[b]{2}{*}{ Ratio } & \multirow[b]{2}{*}{ Value } & \multicolumn{6}{|c|}{ Criteria } & \multirow[b]{2}{*}{ Conclusion } \\
\hline & & & & 1 & 2 & 3 & 4 & 5 & $\begin{array}{c}\text { Composit } \\
\text { Rating }\end{array}$ & \\
\hline \multirow{5}{*}{2013} & Risk Profile & $\begin{array}{l}\text { NPL } \\
\text { LDR }\end{array}$ & $\begin{array}{c}4,05 \% \\
104,42 \%\end{array}$ & & $\sqrt{ }$ & & $\sqrt{ }$ & & $\begin{array}{c}\text { Health } \\
\text { Less Health }\end{array}$ & \multirow{4}{*}{ Health } \\
\hline & GCG & GCG & 3 & & & $\sqrt{ }$ & & & Health enough & \\
\hline & Earnings & $\begin{array}{l}\text { ROA } \\
\text { NIM }\end{array}$ & $\begin{array}{l}1,79 \% \\
5,44 \%\end{array}$ & $\begin{array}{l}\sqrt{1} \\
\sqrt{ }\end{array}$ & & & & & $\begin{array}{l}\text { Very health } \\
\text { Very health }\end{array}$ & \\
\hline & Capital & CAR & $15,62 \%$ & $\sqrt{ }$ & & & & & Very health & \\
\hline & Composit Value & \multicolumn{2}{|c|}{30} & 15 & 4 & 3 & 2 & - & $24 / 30=80 \%$ & PK 2 \\
\hline \multirow{5}{*}{2014} & Risk Profile & $\begin{array}{l}\text { NPL } \\
\text { LDR }\end{array}$ & $\begin{array}{c}4,01 \% \\
108,86 \%\end{array}$ & & $\sqrt{ }$ & & $\sqrt{ }$ & & $\begin{array}{c}\text { Health } \\
\text { Less Health }\end{array}$ & \multirow{4}{*}{ Health } \\
\hline & GCG & GCG & 2 & & $\sqrt{ }$ & & & & Health & \\
\hline & Earnings & $\begin{array}{l}\text { ROA } \\
\text { NIM }\end{array}$ & $\begin{array}{l}1,14 \% \\
4,47 \%\end{array}$ & $\sqrt{ }$ & & $\sqrt{ }$ & & & $\begin{array}{l}\text { Health enough } \\
\text { Very health }\end{array}$ & \\
\hline & Capital & CAR & $14,63 \%$ & $\sqrt{ }$ & & & & & Very health & \\
\hline & Composit Value & \multicolumn{2}{|c|}{30} & 10 & 8 & 3 & 2 & - & $23 / 30=77 \%$ & PK 2 \\
\hline \multirow{5}{*}{2015} & Risk Profile & $\begin{array}{l}\text { NPL } \\
\text { LDR }\end{array}$ & $\begin{array}{c}3,42 \% \\
108,78 \%\end{array}$ & & $\sqrt{ }$ & & $\sqrt{ }$ & & $\begin{array}{c}\text { Health } \\
\text { Less Health }\end{array}$ & \multirow{4}{*}{ Health } \\
\hline & GCG & GCG & 2 & & $\sqrt{ }$ & & & & Health & \\
\hline & Earnings & $\begin{array}{l}\text { ROA } \\
\text { NIM }\end{array}$ & $\begin{array}{l}1,61 \% \\
4,87 \%\end{array}$ & $\begin{array}{l}\sqrt{ } \\
\sqrt{ }\end{array}$ & & & & & $\begin{array}{l}\text { Very health } \\
\text { Very health }\end{array}$ & \\
\hline & Capital & CAR & $16,97 \%$ & $\sqrt{ }$ & & & & & Very health & \\
\hline & Composit Value & \multicolumn{2}{|r|}{30} & 15 & 8 & - & 2 & - & $25 / 30=83 \%$ & PK 2 \\
\hline \multirow{5}{*}{2016} & Risk Profile & $\begin{array}{l}\text { NPL } \\
\text { LDR }\end{array}$ & $\begin{array}{c}2,84 \% \\
102,66 \%\end{array}$ & & $\sqrt{ }$ & & $\sqrt{ }$ & & $\begin{array}{c}\text { Health } \\
\text { Less Health }\end{array}$ & \multirow{4}{*}{ Health } \\
\hline & GCG & GCG & 2 & & $\sqrt{ }$ & & & & Health & \\
\hline & Earnings & $\begin{array}{l}\text { ROA } \\
\text { NIM }\end{array}$ & $\begin{array}{l}1,76 \% \\
4,98 \%\end{array}$ & $\begin{array}{l}\sqrt{ } \\
\sqrt{ }\end{array}$ & & & & & $\begin{array}{l}\text { Very health } \\
\text { Very health }\end{array}$ & \\
\hline & Capital & CAR & $20,34 \%$ & $\sqrt{ }$ & & & & & Very health & \\
\hline & Composit Value & \multicolumn{2}{|r|}{30} & 15 & 8 & - & 2 & - & $25 / 30=83 \%$ & PK 2 \\
\hline \multirow{5}{*}{2017} & Risk Profile & $\begin{array}{l}\text { NPL } \\
\text { LDR }\end{array}$ & $\begin{array}{c}2,66 \% \\
103,13 \%\end{array}$ & & $\sqrt{ }$ & & $\sqrt{ }$ & & $\begin{array}{c}\text { Health } \\
\text { Less Health }\end{array}$ & \multirow{4}{*}{ Health } \\
\hline & GCG & GCG & 2 & & $\sqrt{ }$ & & & & Health & \\
\hline & Earnings & $\begin{array}{l}\text { ROA } \\
\text { NIM }\end{array}$ & $\begin{array}{l}1,71 \% \\
4,76 \%\end{array}$ & $\begin{array}{l}\sqrt{ } \\
\sqrt{ }\end{array}$ & & & & & $\begin{array}{l}\text { Very health } \\
\text { Very health }\end{array}$ & \\
\hline & Capital & CAR & $18,87 \%$ & $\sqrt{ }$ & & & & & Very health & \\
\hline & Composit Value & \multicolumn{2}{|c|}{30} & 15 & 8 & - & 2 & - & $25 / 30=83 \%$ & PK 2 \\
\hline
\end{tabular}

Source: processed data, 2019 
The results of BTN health level analysis based on the RGEC method during 2013 to 2017 show that BTN's performance is at Composite Rating 2 (PK-2), which is seen from the four aspects measured in the form of risk profile, GCG, earnings, and overall capital in the Healthy rating. . When Indonesia's economic condition is declining, it can be seen from the condition of the BI rate which has been increasing over the years 2013 to 2017, but this is not a barrier for BTN to continue to maintain the overall performance of the company so that it remains ranked very healthy.

\subsection{Discussions}

Risk profile. The financial ratios used in assessing the health of BTN are viewed from the risk profile aspect by using 2 indicators which are credit risk factors using the formula NPL and liquidity risk with the LDR formula. The average value of BTN's NPL during 2013 to 2017 shows that the credit quality of BTN is in a healthy condition. This is in accordance with the NPL ranking determination matrix where BTN's NPL ratio is included in the healthy criteria. The NPL obtained by the BTN during 2013 to 2017 was in accordance with Central Bank of Indonesia standards which stipulated that the ratio of maximum nonperforming loans (NPLs) was 5\%. It is also seen that the value of BTN's NPL is getting smaller from year to year. The smaller NPL value indicates that the BTN is getting better at selecting prospective borrowers so that the number of loans classified as substandard, doubtful and loss is also reduced. This shows that management's efforts in managing the collectability level and maintaining credit quality each year are getting better and giving positive results, so they can produce quality credit growth and not just high and aggressive credit growth. The average value of the BTN's LDR during 2013 to 2017 are above 100 percent which means that based on Central Bank of Indonesia 's determination that the LDR in the range of 100 to 120 percent is categorized as underweight. This indicates that during this period BTN did not have sufficient capacity to fulfill its short-term obligations when billed by depositors by relying on loans provided as a source of liquidity. BTN needs to tighten the amount of credit channeled and still maintain the principle of prudence in the coming years. Because if it has high LDR value then it will show that the bank is too aggressive in lending so that it can increase the risk exposure faced. However, if the LDR value is too low, it will affect the profits obtained because if the LDR is too low this indicates that the amount of credit disbursed decreases. As the decline in loans channeled, the profits generated by banks also decrease. Therefore, the bank needs to maintain the Loan to Deposit Ratio level in the ideal range set by Central Bank of Indonesia at 78-92 percent. During 2013 to 2017 the BTN were seen as not yet able to maintain the bank's LDR in the ideal range.

Good Corporate Governance (GCG). The health level of the bank in terms of the average value of Good Corporate Governance at the BTN in 2013 is getting fairly healthy criteria so that it shows that the quality of BTN's management of the GCG principles is running quite well whereas in 2014 until 2017 BTN obtained an average GCG value of 2 with healthy criteria which increased by one level from the criteria in 2013 . The healthy criteria indicated that in 2014 to 2017 the quality of management of state-owned commercial banks was based on the implementation of GCG principles have been running well, so that in those years BTN was classified as a trusted bank. Good GCG implementation will increase stakeholder confidence in conducting transactions at the bank concerned because by looking at GCG value of a stakeholder bank can find out the risks that might occur when conducting transactions with the bank.

Profitability/earnings. Financial ratios used in assessing the health of state-owned commercial banks in terms of earnings aspects are ROA and NIM. The value of ROA from BTN during 2013 to 2017 fluctuated. It was seen that the ROA from BTN in 2014 decreased from the initial criteria of very healthy in 2013 , decreased to two levels to be quite healthy in 2014 due to the increase in interest rates which generally led to an Increase in Reserves of 
BTN's CKPN. But then in 2015 and 2016, the BTN's ROA ratio increased which showed that the ROA from BTN was categorized as very healthy, even though in 2017 it fell again but remained in the very healthy category. This shows that BTN's ability to earn profits by relying on its assets has gone very well. NIM from BTN in 2013 until 2017 shows that in 2013 the value of NIM was far above 3\% as standard criteria for very healthy criteria by Central Bank of Indonesia which showed that BTN's net interest income was also very good but in 2014 the NIM value declined due to by an increase in interest rates which caused high interest costs borne by BTN that year. But overall, the value of NIM shows that BTN's ability to obtain net interest income for five years has been very good. This is in accordance with the NIM ranking matrix where the ratio of NIM> 3\% is included in the criteria of very healthy. So that it can be indicated that during 2013 to 2017 BTN had excellent bank management capabilities in managing its productive assets to generate net interest income for the company.

Capital. The health level of bank in terms of the Capital aspect by calculating the Capital Adequacy Ratio (CAR) at BTN in 2013 to 2017 has a CAR value with very healthy criteria. Even though it was seen that in 2014 the CAR value declined slightly but overall the BTN's CAR was in accordance with the provisions stipulated by Central Bank of Indonesia which is banks must provide a total capital of at least $8 \%$ of RWA. A large CAR indicates that banks can support operational losses if they occur and can support large loans. Large CARs can also increase the trust of the community to channel their funds to BTN banks. The value of CAR held by the BTN during 2013 to 2017 is far above the standard set so that the bank is considered to have been able to fulfill the Minimum Capital Provision Requirement (KPMM).

RGEC aspects (risk profile, good corporate governance, and capital). The assessment of the health level of state-owned commercial banks using the RGEC method which are Risk Profile, Good Corporate Governance, Earnings and Capital during 2013 to 2017, is in composite rating 2 (PK-2) with healthy criteria. Based on Circular Letter of Central Bank of Indonesia No.13/24/DPNP / 2011 banks that obtain composite rating 2 reflect the condition of banks that are generally healthy so that they are considered capable of facing significant negative effects of changes in business conditions and other external factors reflected in the ranking of factors assessment factors, including risk profiles, implementation of GCG, profitability, and capital that are generally good. If there are weaknesses, in general these weaknesses are less significant.

\section{CONCLUSION}

1. The results of the BTN's Risk Profile assessment using 2 indicators which are credit risk factors using the NPL ratio and liquidity risk with the LDR ratio. The results showed that the BTN NPL value of the bank was categorized into healthy criteria. BTN's NPL is also getting smaller from year to year. The smaller NPL value indicates that the BTN is getting better at selecting prospective borrowers so that the number of loans classified as substandard, doubtful and loss is also reduced. In contrast, over period of 2013 to 2017 the BTN's LDR is above 100 percent or categorized as unhealthy criteria. This indicates that during this period BTN did not have sufficient capacity to fulfill its short-term obligations when billed by depositors by relying on loans provided as a source of liquidity. BTN needs to tighten the amount of credit channeled and still maintain the principle of prudence in the coming years.

2. The results of the BTN's Good Corporate Governance (GCG) assessment in 2013 obtained with a score of 3 with fairly healthy criteria so that the quality of BTN's management on the GCG principle went well. Whereas in 2014 until 2017 the BTN obtained an average GCG value of 2 with healthy criteria which showed that in 2014 to 
2016 the quality of management of state-owned commercial banks on the implementation of GCG principles had gone well, so that in the years BTN is also classified as a trusted bank.

3. The results of assessment the Profitability (Earnings) of state-owned commercial show that BTN's ROA in 2014 decreased from initially included in the very healthy criteria in 2013 to decline to two levels to be quite healthy in 2014, this was caused by an increase in interest rates which generally caused a Reserve for Decreasing Losses BTN value (CKPN). But then in 2015 to 2017, the BTN's ROA ratio increased which showed that the BTN's ROA is categorized as very healthy criteria, this indicates that the ability of BTN to obtain profits by relying on their assets has gone very well. The results of the BTN's NIM ratio assessment for 2013 to 2017 show that NIM value was above 3 percent or included in the very healthy category. This shows that the ability of the BTN to obtain net interest income for five years has been very good. During 2013 to 2017 the BTN has excellent bank management capabilities in managing its productive assets to generate net interest income for the company.

4. The results of BTN's Capital assessment during 2013 are in very healthy condition, this is evidenced by the CAR value of BTN for five years above 11 percent. Although it is seen that in 2014 the CAR value declined slightly but overall the CAR from BTN was in accordance with the provisions set by Central Bank of Indonesia, namely banks must provide a total capital of at least $8 \%$ of RWA. A large CAR indicates that banks can support operational losses if they occur and can support large loans. A large CAR can also increase the trust of the community to channel their funds to BTN.

5. The results of the BTN health level viewed from the aspect of RGEC (Risk profile, Good Corporate Governance, Earnings, and Capital) during 2013 to 2017 occupy Composite Rating 2 (PK-2) which reflects the condition of the bank in a generally healthy manner so that it is considered capable of facing influence significant negatives of changes in business conditions and other external factors are reflected in the ratings of assessment factors, including risk profiles, implementation of GCG, profitability, and generally good capital. If there are weaknesses, in general these weaknesses are less significant.

Based on those conclusions this study suggests that:

For BTN: (1) assessment of the risk profile factor from the aspect of credit risk, the bank management should be more selective in lending to customers and following the credit regulations set by Bank Indonesia to avoid the occurrence of bad credit; (2) assessment of the risk profile factor, from the aspect of liquidity risk, BTN should be one of the state-owned commercial banks that has an LDR ratio that exceeds the maximum limit set by Bank Indonesia to pay more attention to all bank obligations, especially special obligations. short term and try to balance between giving credit with the amount of funds received from third parties so that bank liquidity can be maintained; (3) as a bank with the status of a State Owned Enterprise, BTN should be able to maintain and continue to improve the health of the bank in the following years. The soundness of a bank that is very healthy will increase public trust, customers, employees, shareholders and other parties to the bank.

For further studies: this study only uses the RGEC method to measure the soundness of the Bank. It is necessary to consider a comparison of several methods or instruments to measure the soundness of the bank in order to obtain more comprehensive and accurate calculations and analyzes in calculating bank performance. 


\section{REFERENCES}

Bank Indonesia. 1998. Surat Keputusan Direksi Bank Indonesia No 30/277/KEP/DIR tahun 1998 tentang Perubahan Surat Keputusan Direksi Bank Indonesia Nomor 30/11/KEP/DIR Tanggal 30 April 1997 Tentang Tatacara Penilaian Tingkat Kesehatan Bank Umum. Jakarta: Bank Indonesia.

2004. Peraturan Bank Indonesia No. 6/10/PBI/2004 Perihal Penilian Tingkat Kesehatan Bank Umum. Jakarta: Bank Indonesia. 2004. Surat Edaran Bank Indonesia No.6/23 /DPNP tanggal 31 Mei 2004 Perihal Penilian Tingkat Kesehatan Bank Umum. Jakarta: Bank Indonesia. 2007. Peraturan Bank Indonesia Nomor: 9/7/PBI/2007 Perihal Perubahan Atas Peraturan Bank Indonesia Nomor 8/3/PBI/2006 tentang Perubahan Kegiatan Usaha Berdasarkan Prinsip Syariah dan Pembukaan Kantor Bank Yang Melaksanakan Kegiatan Usaha Berdasarkan Prinsip Syariah oleh Bank Umum. Jakarta: Bank Indonesia.

2007. Surat Edaran Bank Indonesia No. 9/12/DPNP/2007 Perihal Pelaksanaan Good Corporate Governance bagi Bank Umum. Jakarta: Bank Indonesia. 2011. Peraturan Bank Indonesia Nomor: 13/1/PBI/2011 Perihal Penilian

Tingkat Kesehatan Bank Umum. Jakarta: Bank Indonesia. 2011. Surat Edaran Bank Indonesia No.13/24/DPNP Perihal Penilaian Tingkat Kesehatan Bank Umum. Jakarta: Bank Indonesia. . 2011. Lampiran Surat Edaran Bank Indonesia No.13/24/DPNP Perihal Penilaian Tingkat Kesehatan Bank Umum. Jakarta: Bank Indonesia.

Indonesia.

2012. Kodifikasi Penilaian Tingkat Kesehatan Bank. Jakarta: Bank

2014. Booklet Perbankan Indonesia 2014. Jakarta: Bank Indonesia.

Bratanovic, Sonja Brajovic dan Hannie van Greuning. 2009. Analisis Risiko Perbankan. Jakarta: Salemba Empat.

Dendawijaya, Lukman. 2005. Manajemen Perbankan. Jakarta: Penerbit Ghalia Indonesia.

Hasibuan, Malayu. 2009. Dasar-Dasar Perbankan. Jakarta: PT. Bumi Aksara.

Latumaerissa, Julius R.. 2012. Bank dan Lembaga Keuangan Lain. Jakarta: Salemba Empat.

Kasmir. 2012. Analisis Laporan Keuangan. Jakarta: PT. Raja Grafindo Persada. . 2012. Dasar-dasar Perbankan. Edisi Revisi. Jakarta: PT. Raja Grafindo Persada.

Khalil, Muhammad. Raida Fuadi. 2016. Analisis Penggunaan Metode risk profile, good corporate governance, earning, and capital (RGEC) dalam mengukur kesehatan bank pada bank umum syariah di indonesia periode 2012-2014. Jurnal Ilmiah Mahasiswa Ekonomi Akuntansi (JIMEKA) Vol. 1, No. 1, (2016) Halaman 20-35

Martono, Nanang. 2010. Metode Penelitian Kuantitatif Analisis Isi dan Analisis Data Sekunder Edisi Revisi. Jakarta: PT Raja Grafindo Persada.

Kuncoro, Mudrajat dan Suhardjono. 2011. Manajemen Perbankan Teori dan Aplikasi. Yogyakrta: BPFE.

Pramana, Komang Mahendra. Luh Gede Sri Artini. 2016. Analisis tingkat kesehatan bank (pendekatan RGEC) pada PT. Bank danamon indonesia tbk. E-Jurnal Manajemen Unud, Vol. 5, No. 6, 2016: 3849-3878

Rivai, Veithzal, dkk. 2012. Commercial Bank Management:Manajemen Perbankan dari Teori ke Praktik. Jakarta: PT Raja Grafindo Persada.

Sugiyono. 2011. Metode Penelitian Administrasi dilengkapi dengan Metode R\&D. Bandung: Alfabeta.

Arikunto, Suharsimi. 2014. Prosedur Penelitian Suatu Pendekatan Parktik. Jakarta: Rineka Cipta. 
Triandaru dan Budisantoso. 2006. Bank dan Lembaga Keuangan Lain. Edisi Kedua. Jakarta: Salemba Empat.

Budisantoso dan Nuritomo. 2014. Bank dan Lembaga Keuangan Lain. Jakarta: Salemba Empat.

Undang-undang. 1992. Undang-undang No. 7 Tahun 1992, tentang Perbankan. . 1998. Undang-undang No. 10 Tahun 1998, tentang Perbankan.

Wirawan. 2011. Evaluasi Teori, Model, Standar dan Profesi. Jakarta: PT Raja Grafindo Persada. 